\title{
Gender, Mad Scientists and Nanotechnology
}

\author{
J. Kasi Jackson *
}

\begin{abstract}
What does feminism have to do with nanotechnology? And how do mad scientists demonstrate the connections between the two? To explore this, I examine a case study of mad scientists in film, discussing first why mad scientist images arise and why nanotechnology, or the manipulation of matter on the atomic and molecular scales, may be particularly vulnerable to this kind of representation. National funding agencies are calling for the integration of ethics and societal implications into nanoscience and technology research and the training of future scientists and engineers. This emphasis offers a powerful way to break down stereotypes about science and engineering that discourage the participation of some groups.
\end{abstract}

Bocking $(2007,55-56)$ calls for a "new contract" between science and society that would "enable the construction of knowledge considered credible by all parties" through rigorous peer review (including participation by local knowledge holders), decision-making that is context-dependent and sensitive to local concerns, and research priorities that are set by diverse persons. Toumey (2006) identifies nanoscale science and engineering (NSE) as a potential area within which to experiment with methodologies for democratizing science and encouraging public participation because "[a]fter all, every citizen is a potential stakeholder in nanotechnology in the sense that it will affect everybody's life, even if it is unclear how democratic societies will honour the status of the stakeholder" (6). Though many citizens lack awareness of nanotechnology,

\footnotetext{
* Kasi Jackson is an assistant professor of women's studies at West Virginia University, and a participant in WVNano, West Virginia's nanoscale science and engineering initiative. She completed a PhD in biology (2003), specializing in animal behavior and evolutionary biology, and a graduate certificate in women's studies (2000) at the University of Kentucky in Lexington, $\mathrm{KY}$. She teaches courses on women and nature, women in movies, feminist theory, and women and gender in science. In addition to her work on the application of feminist science studies to nanotechnology, her scholarly efforts include work on the representation of female mad scientists in film, as well as in the area of gender and animal behavior. In addition, she is involved in various efforts to enhance science and engineering education by linking science content to popular culture, as well as societal and ethical issues. She is the Principal Investigator on a grant from the National Science Foundation's Robert Noyce Scholarship program to set up a program to provide scholarships for WVU students to graduate with a science or math degree and a master's in education through WVU's Benedum Collaborative 5 year teacher training program. The 20 students will teach 6 years in high need schools in WV in exchange for 3 years of $\$ 10,000$ scholarships. She is also a co-Investigator on an NSF funded project to develop an Undergraduate Emphasis Area in Nanosystems at WVU.
}

Spontaneous Generations 2:1 (2008). ISSN 1913-0465. University of Toronto 
Toumey argues that "[...] many non-experts can acquire, comprehend and deploy technical knowledge when they need to" and, thus, "[...] participatory democracy and upstream public engagement are feasible for non-experts who want a voice in science policy" (7). Using perspectives from feminist science studies to integrate teaching about societal and ethical issues with NSE content provides one set of strategies to provide citizens with technical information in a societal context, thus encouraging engagement between scientists and a broad, diverse selection of public groups.

\section{Feminist Responses to Science}

Women have been underrepresented in science and engineering, and so a key issue for the feminist scholar is to determine why this is so. As part of this work, researchers look at the history of science and recognize overlooked contributions by women; they look at the structure of the current educational system and workforce to identify barriers that exclude women; and they make specific recommendations to improve women's representation in the sciences, engaging particularly with the issue of whether women must change to succeed in science or whether science itself must be changed to accommodate women. Of course, scholars attend to the interactions among gender and other social factors, such as socioeconomic status, race/ethnicity, able-bodiedness/disability, and sexuality, as well as the differences among scientific fields.

In addition, scholars of feminist science studies examine the structure of scientific knowledge itself. Feminists want to ensure that gender is included as a category of analysis in three respects. First, both men and women must be included in scientific research. Second, feminists critique research that specifically addresses gender differences, particularly when such work bolsters sexist assumptions about male and female abilities that limit women's achievements. A third area concerns the broader construction of knowledge itself. From the perspective of many scholars of feminist science studies the question "Who does science?" is inextricably linked to the question of how science is done (see, for example, Harding 1991; Longino 1990; Haraway 1989; or Schiebinger 1993, among others.) The pertinent ethical questions then become "Can all participate in the practice of science and the setting of research priorities?" and "Do all share in the risks and benefits of scientific research?" The ultimate goal is a science knowledge system that furthers social justice.

Feminist participatory research methods provide one means to this end. According to Fortmann, Ballard and Sperling:

[...] participatory biophysical research is inherently collaborative. It is intentionally not exploitative of research partners. It is, of necessity, knowingly embedded in a social and political context, which is taken into explicit account in the research process and reflective practice. Interactions with research collaborators lead participatory researchers to assess their categories and assumptions critically and mutually. [italics in source] $(2008,82)$ 
They focused on collaborations between traditional scientific experts and local people in research projects on forest ecology (the Pacific Northwest's Olympic Peninsula, Washington State) and plant breeding (Rwanda, Burundi and Congo). In the first case, floral greens (salal or lemon leaf) harvesters worked with researchers to collect data and modify forest management practices to promote the salal harvest. As a result, "[...] university and natural resource agency ecologists learned that a marginalized group without formal education are very important knowledge producers" (87). In the second case, "[t]he premise was not that 'poor women farmers knew more than scientists' (who were overwhelmingly male) but rather that 'female expertise was highly specialized, crucial for increasing plant breeding impact, and complemented select strengths of formal scientists'" (88). What sparked the collaboration was the fact that only 10 percent of the approximately 50 bean varieties tested on farms were being planted-why weren't farmers adopting more varieties? Women, who select seeds for subsistence crops, looked at a wider range of traits than conventional breeders (e.g. tolerance for climate stress, ability to grow in varying circumstances, cooking time, texture, etc., in addition to pest resistance and yield). As a result of the collaboration, the adoption rates of new bean varieties improved and yields also increased (88-90).

NSE is an ideal area in which to link the "who" and "how" questions and pursue democratic science because of the current emphasis on the integration of societal and ethical factors by the U.S. National Nanotechnology Initiative and associated funding agencies like the U.S. National Science Foundation. This integration is particularly crucial in science and engineering education both to encourage future scientists and engineers to grapple with the societal and ethical implications of their work and to enhance the broader public's ability to participate in decision-making about nanotechnology and other scientific/technical fields. This project is critical both for NSE researchers and advocates and for those who hope to encourage democratic science because of the revolutionary potential some place on NSE and the potential vulnerability within the field to mad-science imagery.

\section{NSE and Mad-Science Imagery}

The frequency of mad-science characters may be linked to alienation from science or high levels of scientific illiteracy, though market forces frequently exacerbate their negative traits (Toumey 1992). Mad-science images are employed in public debates about scientific research, its ethics, and resultant regulation. For example, both proponents and opponents of in vitro fertilization used references to Frankenstein to make their cases (Mulkay 1996). More recently, genetically modified foodstuffs have been branded by the moniker Frankenfoods. Finally, mad-scientist images might affect who does science, specifically by furthering the image of science and the scientist as detached from 
society, unconcerned with or even antagonistic to addressing societal issues, and, therefore, portraying science as an unattractive career path for those who wish to better society.

NSE is potentially vulnerable to mad-science tropes for several reasons. First, since it is a new research field, its disciplinary definition is still coalescing, leading to confusion about what exactly qualifies as nanotechnology. Sweeney (2006) reviews the ongoing discussion about the definition of the field; the term nanotechnology disguises two distinct approaches: 1 ) Top-down, or manufacture by lithographic, etching, chemical vapor deposition, etc. techniques, and 2) Bottom-up, or building organic and inorganic structures molecule by molecule or atom by atom (self assembly). Most current applications of nanotechnology use top-down approaches. In Engines of Creation, Eric Drexler argued that nanotechnologies arising from the bottom-up process of self-assembly would radically alter human society and offer endless possibilities for human modification, cheap energy, and amazing devices. However, self-assembly is highly speculative and has also given rise to the "grey goo" scenario, in which self-assembling nano-bots reproduce out of control and destroy the world (addressed by Drexler and most prominently publicized in Michael Crichton's Prey). This fear was popularized by a debate between Drexler and Rick Smalley where Smalley described reading essays by schoolchildren in which they were fearful of the effects of nanotechnology and wrote to Drexler that "[y]ou and people around you have scared our children. [...] [W] hile our future in the real world will be challenging and there are real risks, there will be no such monster as the self-replicating mechanical nanobot of your dreams" (quoted in Baum 2003). If the top-down and bottom-up approaches are not clearly distinguished, fears arising from the "grey goo" scenario may become associated with topdown manufacturing approaches as well, leading to resistance to these technologies on the basis of incorrect assumptions; or, as Schummer notes, if the blanket term nanotechnology covers different fields and approaches then "personal fears and hopes about one technology may spread over and contaminate all other 'nanotechnologies' without reason" $(2006,219)$.

This fear is compounded by the second reason for NSE's vulnerability. Although some national initiatives in NSE include a research component specifically addressing societal and ethical issues and call for study of the societal impacts of NSE, in practice, most initiatives have been put into place with little or no public input (Schummer 2006). The unwillingness or inability of governments to engage the public in decision-making about NSE means that these debates may occur in other places and will sometimes be grounded in suspicion. For example, many labour, environmental, and other social justice groups recently signed a statement urging a precautionary approach to nanotechnology and stronger regulation because of the unknown effects on economies, the environment, and human health. The statement reflects not only an awareness of potential risks and a desire to mitigate those but also specifically cites the lack of public participation in decision-making as an aggravating factor (Principles for 
Nanotechnologies and Nanomaterials Oversight 2007, 1). The signatories urge mandatory regulation because "[v]oluntary initiatives often delay or weaken essential regulation, forestall public involvement, and limit public access to vital environmental safety and health data" (3). The statement specifically condemns "after-the-fact, one-way public 'engagement' in which the government and/or industry 'educates' the public with the goal of quelling debate and smoothing public acceptance" (6). This undesirable type of engagement could be exemplified by some applications of the "deficit model" approach in which the public's suspicion of science is assumed to be because of a lack of scientific knowledge that can be rectified if scientists communicate with the public. According to Toumey, problematic examples of this approach include postChernobyl attempts to protect people from contaminated animals and the UK government's response to mad cow disease $(2006,6)$. As an alternative, the South Carolina Citizens' School of Nanotechnology (SCCSN) provided a format in which citizens receive technical information from NSE research in a context where their participation and feedback are solicited (Toumey, Reynolds, and Aggelopoulou 2006). As a result, one researcher said that "[...] although the SCCSN had not changed the direction of her research, 'the participants' insistence in knowing how the various aspects of my research are important and relevant has forced me to face the same questions'" (6).

In spite of the attention that nanotechnology has attracted, the public remains largely unaware of research in and applications arising from NSE. This provides the third reason that nanotechnology is vulnerable to mad-science imagery. Waldron, Spencer and Batt asked respondents to define nanotechnology; they found that "[m]any respondents offered science fiction worthy definitions of 'robots', 'nanobots' and 'tiny cameras that are injected into your body' suggesting that their knowledge originates with popular fiction" $(2006,573)$. A recent survey found that $6 \%$ of the public had heard "a lot about it'", 21\% had heard "some", 29\% had heard "just a little", and 42\% had heard "nothing at all" (Hart 2007,4). 51\% of the respondents said that they were not sure about the risks-versus-benefits tradeoff. $25 \%$ felt risks and benefits would be about equal, $18 \%$ thought benefits would be greater and $6 \%$ felt risks would be greater (7). However, after the respondents heard a short statement about nanotechnology including both benefits and risks, the proportion that increased the most was the one that said that risks would outweigh benefits (7-8). Women, older people, persons with lower income levels and less education were less likely to have heard of nanotechnology (5). In addition, women were more likely to shift toward the belief that the risks would outweigh the benefits (8). Ironically, the authors note that "[...] women are the primary purchasers of many of the consumer products enhanced with nanotechnology that are already on the market, such as dietary supplements, anti-aging products, and other cosmetics" (12). Further, questions asked by women participants in the SCCSN 
were skewed towards the societal implications of the technology, whereas male participants' questions were more evenly balanced between technical and societal issues (Toumey et al. 2006, 6).

Overall, the results of these surveys indicate that in the event of negative news, public opinion could shift dramatically-thus mad-science imagery could have a ready audience. However, perceptions of nanotechnology are complex. Cobb and Macoubrie found that people who had read Prey were more likely to say that nanotechnology's benefits would outweigh its risks $(2004,401)$; however, they conclude that some of this may be due to the demographic characteristics of people likely to have read Prey. There is considerable variation in cultural acceptance of nanotechnology as well. In one recent survey, people in the U.S. were less likely to agree that nanotechnology is morally acceptable than people in Europe, even when they were informed about the technology and knew of its potential benefits. The researchers argue that "[t]he catch for Americans with strong religious convictions [...] is that nanotechnology, biotechnology and stem cell research are lumped together as means to enhance human qualities. In short, researchers are viewed as 'playing God' when they create materials that do not occur in nature [...]" (Devitt 2008). Overall, these findings point to the variation among countries in the public's view of novel technologies like NSE.

Promises that NSE will provide the ultimate control over nature contribute to the "playing God" image. Lopez (2004) argues that "[...] the central metaphor in NST discourse-nanotechnoscientists as master builders [...]" limits ethical discussion because the goals of NSE are assumed to be desirable and hence are not open to critique. Technologies are assumed to underlie all social change and non-technological solutions are rejected. Finally, Lopez argues that humanists and social scientists become engaged with overcoming public resistance, rather than thinking through the implications of the technology. Ultimately, opponents will counter with dystopian narratives.

\section{Gender, Mad Scientists and Nature}

The promise of ultimate control over nature connects to the gendering of the mad scientist, and is succinctly represented in Mel Brooks's parody Young Frankenstein. While Frankenstein (Gene Wilder) and corpse are hoisted toward the lightning-filled sky, Frankenstein proclaims that he wants to "penetrate into the very womb of impervious nature herself". Parodies, such as Young Frankenstein, exaggerate themes present in more "serious" films, thus highlighting assumptions inherent in the source material. In Western culture, science has been associated with presumed "masculine" traits such as rationality, objectivity and the lack of emotion. In dualistic systems, these "masculine" traits are opposed by essentialized "feminine" traits like irrationality, empathy, and emotion. In addition, nature has been persistently gendered feminine (as in Mother Nature), and metaphorically, masculine science has been seen as the tool to penetrate the secrets of feminine nature with the 
goal of control for Man's benefit. These depictions spring from the gendering of the science/nature relationship located by many feminist scholars in the origins of science itself. According to Keller, "To see the emphasis on power and control so prevalent in the rhetoric of Western science as projection of a specifically male consciousness requires no great leap of the imagination. [...] Above all, it is invited by the rhetoric that conjoins the domination of nature with the insistent image of nature as female [...]" $(1996,36)$.

Given the vulnerability of NSE to mad-science imagery and the gendered nature of this imagery, what are the consequences for diversity in the scientific workforce? Studies in which respondents (frequently children) are asked to draw or describe a scientist provide a particularly pertinent example. The drawings and/or descriptions reflect stereotypes consistent with imagery of mad scientists. In particular, the scientists are isolated from society-their laboratories are plastered with "Keep Out" and "Top Secret" signs (reviewed in Frayling 2005, 12-16). This view of science as separate from, and even dangerous to society, could contribute to the persistent lack of diversity in some scientific fields. There is evidence that when teachers put science and math in the context of societal issues-for example, by discussing how the subjects can benefit society-this can encourage students, particularly women, to take an interest in science and engineering (Busch-Vishniac and Jarosz 2004; Weston, Seymour and Thiry 2006). Representations which fail to make these vital connections arise in part because '[...] scientists' attitudes towards the public, the media and their own image have themselves become barriers to the communication with the public they themselves seek" (Frayling 2005, 46). To further illustrate the problems that arise due to this barrier, I will turn to another fictional mad scientist-this one a woman.

So, what happens to the science/nature relationship if the mad scientist is female? Though Flicker argues that "[f]emale characters in feature films do not contribute to the build up of negative myths surrounding science" $(2003,316)$, Steinke discusses some examples of negative portrayals (2005, 40 and 42), though she also notes that the characterization is unusual. The tensions between woman's relationship to science and her relationship to nature make the female scientist an ideal figure upon which filmmakers can project societal anxieties about the science/nature relationship. Her utility in this regard arises from the location of women in the realm of nature, as opposed to that of science. The depiction of real women scientists, like Jane Goodall and Dian Fossey, in National Geographic videos positions Woman as the intermediary between Man and Nature (Haraway 1986). In the realm of fictional films, the mad female scientist uses science to protect nature rather than dominate it. Dr. Jane Tiptree (Dianne Ladd) from Carnosaur provides a particularly clear example. Alaimo (1997) argues that Tiptree represents societal anxiety when the power of science is placed in a woman's hands. For example, Tiptree seeks to destroy all humans 
because of humanity's destruction of nature (and to pay for her own genetic engineering which resulted in the extinction of a grasshopper sub-species). She engineers a virus that will cause human females to give birth to dinosaur eggs, resulting in the replacement of humans by dinosaurs. The filmmakers are clearly playing with gendered stereotypes-Tiptree is feminized in comparison to the other female characters. For example, she is the only one who wears make-up. Her femininity is clearly maternal-however, the images of maternity (and of nature) presented in the film are not gentle and nurturing. Rather, they are violent and dangerous, for, as Tiptree explains (quoting Dr. Moreau, whom she identifies as her mentor), "to understand nature, one must become as remorseless as nature herself". Overall, Tiptree is positioned as a vengeful Mother Nature, who will destroy humanity to save the Earth and populate it with her dinosaur children.

However, the makers of the film were also making a larger reflection upon the dangers of a science that is controlled by military, industry and government interests, rather than guided by what will benefit the public. Adam Simon, director of Carnosaur, explained when comparing his film to Jurassic Park: "We could be smarter, in some ways, because when you make a $\$ 100$ million movie, you're making a corporate product that has to please millions of people, so no matter how beautifully you do it, it has to be somewhat debased on the level of ideas. We could be more political than they could be. And we could be grosser" (quoted in Biodrowski 1993, 23). Though the film is ostensibly based on a book by the same name, its plotting is in fact closer to two science fiction stories written by Alice Sheldon, using her alter egos James Tiptree, Jr. ("The Last Flight of Dr. Ain") and Raccoona Sheldon ("The Screwfly Solution"). Sheldon completed a Ph.D. in experimental psychology, and much of her work has been read as warnings that humanity's negative traits, specifically male aggression, could lead to our species' doom. Though Sheldon felt that science, particularly understanding human evolution, could provide a solution, in many of her stories, scientists "[...] look and call and point unheeded, and die looking on what they've found" (quoted in Phillips 2006, 226). Thus, in accordance with Sheldon's pessimistic outlook, Carnosaur is ultimately apocalyptic-to contain the virus, FEMA agents kill the infected townspeople and inadvertently destroy the cure for the virus. Overall, science is presented as a tool for government, industry, and the military to use to the detriment of ordinary citizens. Jane Tiptree's attempts to save the planet create more destruction because she fails to see that the outcomes of her scientific methods are predetermined by their origins in a secretive military-government-industrial complex motivated by profit, rather than public benefit.

Given the potential benefits and risks of nanotechnology, coupled with hype about both, some funding agencies are calling for the integration of ethics and societal implications into nanoscience and technology research and the training of future scientists and engineers. Therefore, NSE offers a potentially powerful site within which to develop educational strategies to democratize science by 
engaging a diverse pool of students and future leaders, researchers, and teachers. However, in these teaching strategies, as well as in more informal outreach and engagement efforts, it is critical to engage participants with a discussion of the agendas of the various stakeholders, agencies, researchers and other groups at the table. Most feminist critiques emphasize the embeddedness of knowledge in specific and local contexts for this very reason, for, as feminist philosopher Helen Longino suggests, only an interrogation of the socially constructed nature of knowledge can answer the most pertinent question: "How can the value of scientific research as a source

of guidance for policy decisions be maintained in the face of the complexity of nature and the partiality and plurality of our knowledge of it?" $(2002,202)$.

\author{
J. KASI JACKSON \\ Assistant Professor \\ West Virginia University \\ Center for Women's Studies \\ 210 Eiesland Hall \\ PO Box 6450 \\ Morgantown, WV 26506-6450 \\ 304-293-2339 ext. 1154 \\ Fax: 304-293-3041 \\ Kasi.Jackson@mail.wvu.edu
}

\title{
References
}

Alaimo, S. 1997. Endangered Humans? Wired Bodies and the Human Wilds in Carnosaur, Carnosaur 2, and 12 Monkeys. Camera Obscura 40-41 (May): 22744.

Baum, R. 2003. Nanotechnology: Drexler and Smalley Make the Case For and Against "Molecular Assemblers". Chemical \& Engineering News 81(48): 37-42. http://pubs.acs.org/cen/coverstory/8148/8148counterpoint.html.

Biodrowski, S. 1993. 'Jurassic Wannabe: Carnosaur!' Cinefantastique 24(2): 23, 60.

Bocking, S. 2007. Wild or Farmed? Seeking Effective Science in a Controversial Environment. Spontaneous Generations 1(1): 48 - 57.

http://ips.library.utoronto.ca/index.php/SpontaneousGenerations/issue/view $\angle 76$.

Busch-Vishniac, I. J. and J.P. Jarosz. 2004. Can Diversity in the Undergraduate Engineering Population Be Enhanced through Curricular Change? Journal of Women and Minorities in Science and Engineering 10(3): 255-281.

Cobb, M. D. and J. Macoubrie. 2004. Public Perceptions about Nanotechnology: Risks, Benefits and Trust. Journal of Nanoparticle Research 6: 395-405. 
Devitt, T. 2008. News Release: Study: Religion Colors Americans' Views of Nanotechnology. D. Scheufele and E. Corley. Paper presented at the annual meeting of the American Association for the Advancement of Science, Boston, Feb. 15, 2008.

Flicker, E. 2003. Between Brains and Breasts-Women Scientists in Fiction Film: On the Marginalization and Sexualization of Scientific Competence. Public Understanding of Science 12: 307-318.

Fortmann, L., Ballard, H. and L. Sperling. 2008. Change Around the Edges: Gender Analysis, Feminist Methods, and Sciences of Terrestrial Environments. In Gendered Innovations in Science and Engineering, ed. Londa Schiebinger. Stanford, CA: Stanford University Press.

Frayling, C. 2005. Mad, Bad and Dangerous? The Scientist and the Cinema. London: Reaktion Books, Ltd.

Harding, S. 1991. Whose Science, Whose Knowledge? Thinking from Women's Lives. Ithaca, N.Y.: Cornell University Press.

Hart Research Associates. 2007. Awareness of and Attitudes toward Nanotechnology and Federal Regulatory Agencies Based on a National Survey among Adults, Conducted on Behalf of: Project On Emerging Nanotechnologies, The Woodrow Wilson International Center For Scholars. http://www.nanotechproject.org/news/archive/ poll reveals public awareness nanotech/.

Haraway, D. 1986. Primatology is Politics by Other Means. In Feminist Approaches to Science, ed. R. Bleier. New York: Pergamon Press.

Haraway, D. 1989. Primate Visions. New York: Routledge.

Keller, E. F. 1996. Feminism and Science. In Feminism and Science, eds. E. F. Keller and H. Longino. New York: Oxford University Press, Inc.

Longino, H. 1990. Science as Social Knowledge. Princeton, N.J.: Princeton University.

Longino, H. 2002. The Fate of Knowledge. Princeton, N.J.: Princeton University Press.

Lopez, J. 2004. Bridging the Gaps: Science Fiction in Nanotechnology. HYLEInternational Journal for Philosophy of Chemistry 10(2): 129-152. http://www.hyle.org/journal/issues/10-2/lopez.htm.

Mulkay, M. 1996. Frankenstein and the Debate over Embryo Research. Science, Technology, and Human Values 21(2): 157-176.

Phillips, J. 2006. James Tiptree, Jr.: The Double Life of Alice B. Sheldon. New York: St. Martin's Press.

Principles for the Oversight of Nanotechnologies and Nanomaterials. 2007. http://www.foeeurope.org/activities/nanotechnology/Documents/ Principles Oversight Nano.pdf.

Schiebinger, L. 1993. Nature's Body: Gender in the Making of Modern Science. Boston: Beacon Press.

Schummer, J. 2006. Cultural Diversity in Nanotechnology Ethics. Interdisciplinary Science Reviews 31(3): 217-230. 
Steinke, J. 2005. Cultural Representations of Gender and Science: Portrayals of Female Scientists and Engineers in Popular Films. Science Communication 27(1): 27-63.

Sweeney, A. 2006. Social and Ethical Dimensions of Nanoscale Science and Engineering Research. Science and Engineering Ethics 12(3): 435-464.

Toumey, C. 1992. The Moral Character of Mad Scientists: A Cultural Critique of Science. Science, Technology, and Human Values 17(4): 411-437.

Toumey, C. 2006. Science and Democracy. Nature Nanotechnology 1: 6-7.

Toumey, C., J. R. Reynolds, and A. Aggelopoulou. 2006. Dialogue on Nanotech: The South Carolina Citizens' School of Nanotechnology. Journal of Business Chemistry 3(3): 3-8.

Waldron, A. M., D. Spencer, and C. A. Batt. 2006. The Current State of Public Understanding of Nanotechnology. Journal of Nanoparticle Research 8: 569575.

Weston, T., E. Seymour, and H. Thiry. 2006. Evaluation of Science Education for New Civic Engagements and Responsibilities (SENCER) Project.

http://www.sencer.net/Assessment/pdfs/Assessment/ FINAL_REPORT_SENCER_12 21 06.pdf.

Filmography

Carnosaur. 1993. DVD. Directed by Adam Simon. 83 min. New Horizons. Young Frankenstein. 1974. DVD. Directed by Mel Brooks. 106 min. $20^{\text {th }}$ Century Fox. 